\title{
Inhibition of Platelet Function by an Aspirin-insensitive Endothelial Cell ADPase Thromboregulation by Endothelial Cells
}

\author{
Aaron J. Marcus, Lenore B. Safier, Katherine A. Hajjar, Harris L. Uliman, Naziba Islam, M. Johan Broekman, and Ana M. Eiroa \\ Divisions of Hematology-Oncology, Departments of Medicine and Pathology, Department of Veterans Affairs Medical Center, \\ New York 10010; and Cornell University Medical College, New York 10021
}

\begin{abstract}
We previously reported that platelets become unresponsive to agonists when stimulated in combined suspension with aspirintreated human umbilical vein endothelial cells. Inhibition occurred concomitant with metabolism of platelet-derived endoperoxides to prostacyclin by endothelial cells. We now demonstrate that if aspirin-treated platelets which fully respond to appropriate doses of agonists are exposed to aspirin-treated endothelial cells, they remain unresponsive despite absence of prostacyclin. Platelet inhibition is due in large part to ectoADPase activity on the endothelial cells. This was established by incubating aspirin-treated endothelial cells with ${ }^{14} \mathrm{C}$-ADP. Radio-thin layer chromatography and aggregometry demonstrated that ${ }^{14} \mathrm{C}$-ADP and induction of platelet activation decreased rapidly and concurrently. AMP accumulated transiently, was further metabolized to adenosine, and deaminated to inosine. The apparent $K_{m}$ of the endothelial cell ADPase was $33-42 \mu \mathrm{M}$ and the $V_{\max } 17-43 \mathrm{nmol} / \mathrm{min}$ per $10^{6}$ cells, values in the range of antithrombotic potential.

Thus, at least three complementary systems in human endothelial cells control platelet responsiveness: a cell-associated, aspirin-insensitive ADPase which functions in parallel with fluid phase autacoids such as the aspirin-inhibitable eicosanoids, and the aspirin-insensitive endothelium-derived relaxing factor. (J. Clin. Invest. 1991.88:1690-1696.) Key words: nucleotidases $\bullet$ cell-cell interactions $\bullet$ platelet aggregation $\bullet$ platelet serotonin release $\bullet$ thrombosis
\end{abstract}

\section{Introduction}

Realization of the importance of vascular cell-cell interactions and transcellular metabolism has increased in recent years (1). This is particularly pertinent to the case of endothelial cells and platelets. Currently we hypothesize that endothelial cells control platelet reactivity via at least three mechanisms: a cell-associated ADPase system and two fluid phase reactants; eicosanoids such as prostacyclin $\left(\mathrm{PGI}_{2}\right)^{1}$; and the endothelium-derived relaxing factor (EDRF). In this report we extend previous

Address correspondence to Aaron J. Marcus, M.D., Thrombosis Research Laboratory, Room 13028AW, Department of Veterans Affairs Medical Center, 423 E. 23rd Street, New York, NY 10010.

Received for publication 17 December 1990 and in revised form 22 July 1991.

1. Abbreviations used in this paper: ASA, acetylsalicylic acid, aspirin; EC, endothelial cell(s); EDRF, endothelium-derived relaxing factor; 5-HT, serotonin, 5-hydroxytryptamine; NO, nitric oxide; $\mathrm{PGI}_{2}$, prostacyclin; PRP, platelet-rich plasma.

The Journal of Clinical Investigation, Inc.

Volume 88, November 1991, 1690-1696 studies on platelet inhibition by $\mathrm{PGI}_{2}$ formed by aspirin-treated endothelial cells from platelet endoperoxides (2). Under experimental conditions in which EDRF was not measurable, we found that platelet reactivity was inhibited by endothelial cells even though both cell types were aspirin treated and $\mathrm{PGI}_{2}$ was absent. Biochemical and functional data will be presented indicating that these aspirin-treated endothelial cells inhibit platelet function largely via a mechanism involving metabolism of ADP and consequent loss of its proaggregatory activity.

\section{Methods}

Preparation of platelet-rich plasma and platelet suspensions. Blood was collected from donors $\sim 12 \mathrm{~h}$ after they had ingested $650 \mathrm{mg}$ acetylsalicylic acid, aspirin (ASA). Platelet-rich plasma (PRP) was prepared using acid citrate-dextrose (citric acid, $38 \mathrm{mM}$; sodium citrate, $75 \mathrm{mM}$; glucose, $135 \mathrm{mM}$ ) as anticoagulant (3), with an initial whole blood centrifugation at $200 \mathrm{~g}, 15 \mathrm{~min}\left(25^{\circ} \mathrm{C}\right)$ and a second centrifugation of the PRP ( $90 \mathrm{~g}, 10 \mathrm{~min}$ ) to eliminate most of the residual erythrocytes and leukocytes. PRP was maintained at room temperature under 5\% $\mathrm{CO}_{2}$-air.

Platelet suspensions, when used, were prepared from PRP as described previously (3). Final resuspension was in cold $0.15 \mathrm{M} \mathrm{NaCl}$ to a count of $1 \times 10^{8}$ platelets $/ 20 \mu$ l. The suspension was kept in a closed container at $4^{\circ} \mathrm{C}$.

Preparation of endothelial cell suspensions. Cultured human endothelial cells (P2-P8) derived from umbilical cords (4) were treated with $1 \mathrm{mM}$ ASA $(10 \mu \mathrm{l}$ of $1 \mathrm{M}$ ASA in ethanol $/ 10 \mathrm{ml})$ for $30 \mathrm{~min}$ at $37^{\circ} \mathrm{C}(2)$. Cells were washed in Hepes-buffered saline and detached with collagenase-EDTA-BSA solution (4). An equal volume of human serum-containing medium was added, the cells centrifuged at $500 \mathrm{~g}$ for $10 \mathrm{~min}$ $\left(22^{\circ} \mathrm{C}\right)$, and finally resuspended in ASA-free buffer $(0.25 \mathrm{ml} / \mathrm{T}-75$ flask). Resuspension buffer was either Tris-Saline-Glucose (TSG) (Tris, $15 \mathrm{mM} ; \mathrm{NaCl}, 134 \mathrm{mM}$; glucose, $5 \mathrm{mM}, \mathrm{pH} 7.4$ ) or Hepes, $5 \mathrm{mM}$; $\mathrm{NaCl}, 140 \mathrm{mM} ; \mathrm{KCl}, 5 \mathrm{mM} ; \mathrm{CaCl}_{2}, 1.29 \mathrm{mM} ; \mathrm{MgCl}_{2}, 1.20 \mathrm{mM}, \mathrm{pH}$ 7.45. Indomethacin was then added to a concentration of $10 \mu \mathrm{M}$. Suspensions were generally maintained at room temperature or at $4^{\circ} \mathrm{C}$ as specified. Endothelial cell (EC) counts averaged 4,466 cells $/ \mu \mathrm{l}$.

Aggregation studies with combined suspensions of ASA-treated platelets and ASA-treated EC. These experiments were carried out similarly to those previously reported in which ASA-treated EC, but untreated platelets were studied (2). ASA-PRP containing $1 \times 10^{8}$ platelets or ASA-treated washed platelets $\left(1 \times 10^{8}\right)$ in buffer were preincubated $\left(3 \mathrm{~min}, 37^{\circ} \mathrm{C}\right)$ in siliconized cuvettes containing stirring bars in an aggregometer. When used, SOD or other substances of interest such as hemoglobin, $\mathrm{FeSO}_{4}$, or nitroprusside were included with the platelets or during preincubation. ASA-treated EC were then added, followed in $1 \mathrm{~min}$ by the agonist. In the case of TSG buffer, which contained no calcium, $\mathrm{Ca}^{++}(3 \mathrm{mM})$ was included $15 \mathrm{~s}$ before thrombin or collagen. Total volumes were adjusted to $500 \mu \mathrm{l}$ with buffer. The aggregation response was recorded over a 5-min period in a Lumiaggregometer (Chrono-Log Corp., Havertown, PA). Control "platelet-poor" cuvettes contained equal numbers of EC to those in "platelet-rich" cuvettes in order to correct for light absorption by the nonaggregating EC. 
Studies of possible inhibitory properties of ASA-EC supernatants. EC were tested for their inhibitory activity as above, using ADP, thrombin, or collagen as platelet agonist. Separate aliquots of EC were equilibrated at $37^{\circ} \mathrm{C}$ in polypropylene microfuge tubes with stirring (in the presence or absence of SOD, $60 \mathrm{U} / \mathrm{ml}$ ). They were then incubated $(15 \mathrm{~s})$ with specific EC stimuli such as bradykinin $(100 \mathrm{nM})$, acetylcholine $(2 \mu \mathrm{M})$, histamine $(10 \mu \mathrm{M})$, or thrombin $(1.25 \mathrm{U} / \mathrm{ml})$, followed by rapid centrifugation (10 s, 15,600 g; Eppendorf Inc., Fremont, CA). Supernatants were transferred to aggregometer cuvettes containing 1 $\times 10^{8}$ ASA-treated platelets (either washed or in PRP). Platelet agonists (ADP, collagen, or thrombin; see below) were added 15-20 s later. Total volumes in the cuvettes were adjusted to $500 \mu \mathrm{l}$ with buffer. Controls were carried out to evaluate effects of carry-over of EC agonists on platelet aggregation. In the case of thrombin, the quantity carried over served as platelet agonist in the cuvette.

Time course of EC ADPase activity. ASA-EC in a total volume of $400 \mu$ l, plus $15 \mu \mathrm{M}\left({ }^{14} \mathrm{C}\right)$ ADP $(41.7 \mathrm{mCi} / \mathrm{mmol}$; New England Nuclear, Boston, MA), or buffer plus $\left({ }^{14} \mathrm{C}\right) \mathrm{ADP}$ for controls, were incubated as in the other centrifugation studies for varying periods of time (15s-30 $\mathrm{min})$. Stirring bars were rapidly removed and the tubes centrifuged as above. A $100-\mu \mathrm{l}$ aliquot of supernatant was transferred to the cuvette containing platelets and the aggregation response recorded. In control experiments containing no EC, the final ADP concentration in the cuvettes was $3 \mu \mathrm{M}$

Immediately after removal of the initial $100 \mu \mathrm{l}$ of supernatant, an additional $200 \mu \mathrm{l}$ was placed in a polypropylene microfuge tube containing $10 \mu \mathrm{l}$ of "stop solution" (5). The stop solution stock consisted of $160 \mathrm{mM}$ disodium EDTA, neutralized to $\mathrm{pH} 7$, plus $17 \mathrm{mM}$ ADP in ice-cold physiological saline. The stop solution was added to prevent any possible further degradation of ADP. Tubes were then vortexed and kept on ice until the experiment was concluded. Scintillation counting was performed on $5 \mu \mathrm{l}$ from each sample. Tubes were stored at $-70^{\circ} \mathrm{C}$ for thin-layer chromatography of ADP and its metabolites.

Incubations could also be carried out with endothelial cell monolayers in multiwell plates (well capacity $1.5 \mathrm{ml}$, growth area $2 \mathrm{~cm}^{2}$; 3847; Falcon Labware, Becton Dickinson \& Co., Lincoln Park, NJ), without stirring, using the same ADP concentration and total volume. Plates were secured by weights in a $37^{\circ} \mathrm{C}$ water bath. At indicated time intervals, supernatants were aspirated and centrifuged as above.

The well system was also used to determine the ADPase activity of fresh endothelial cells. Cells derived from two cords were pooled and divided between nine wells. Within 1-2 h of incubation, the endothelial cells were adherent. This permitted assay of EC ADPase activity free from contaminating erythrocytes, which were discarded in the supernatant.

Aggregation studies using supernatants of either thrombin-stimulated platelets or thrombin-stimulated platelet-endothelial cell mixtures as platelet agonist. Washed platelets $\left(1 \times 10^{8}\right)$ from a donor who had ingested aspirin, or platelets plus $2 \times 10^{6} \mathrm{ASA}$-treated endothelial cells were preincubated for $3 \mathrm{~min}$ and then stimulated with thrombin $(1 \mathrm{U} / \mathrm{ml})$, in the presence of $3 \mathrm{mM} \mathrm{Ca}^{++}$and $20 \mu \mathrm{M}$ hemoglobin. Tota incubation volume was $400 \mu \mathrm{l}$. The microfuge tubes were incubated for 5 min after stimulation, stirring bars removed and centrifugation carried out for $10 \mathrm{~s}$ (Eppendorf). A control tube containing thrombin but no cells was also incubated for $5 \mathrm{~min}$.

$100 \mu \mathrm{l}$ of supernatant was rapidly transferred to an aggregometer cuvette containing $227 \mu \mathrm{l}$ of PRP from the same donor $\left(1.3 \times 10^{8}\right.$ platelets) and buffer (total volume of the assay cuvette was $500 \mu \mathrm{l})$. The aggregation response was recorded for 4 min.

TLC studies of nucleotides, nucleosides, and bases. TLC was carried out on fluorescent silica gel $60 \mathrm{~F}_{254}$-coated plastic sheets (20 $\times 20 \mathrm{~cm}$; EM Separations, Gibbstown, NJ). $15 \mu \mathrm{l}$ of radioactive sample was applied and dried under a stream of air. At each point of application, $2 \mu \mathrm{l}$ of a mixture of standards was added and dried. The standard mixture consisted of $2 \mathrm{mg}$ each of the following compounds: ATP, ADP, AMP, inosine, hypoxanthine, adenosine, and adenine in distilled water (total vol $=1 \mathrm{ml}$ ) (6). The solvent system for nucleotides, nucleosides, and bases consisted ot 1sobutyl alcohol/1-pentanol/ethylene gly- col monoethyl ether $/ \mathrm{NH}_{4} \mathrm{OH} / \mathrm{H}_{2} \mathrm{O}$ (90:60:180:90:120) (solvent 1) (6). For separation of hypoxanthine and adenosine, the solvent system consisted of 1-butanol/ethyl acetate/methanol/ $\mathrm{NH}_{4} \mathrm{OH} \quad(7: 4: 3: 4)$ (solvent 2) (7).

Solvent systems were prepared at least $48 \mathrm{~h}$ before use and added to the tank $1 \mathrm{~h}$ before insertion of plates (8). Development of plates was carried out for $5 \mathrm{~h}, 10 \mathrm{~min}$ in solvent 1 , or $4 \mathrm{~h}$ in solvent 2 . Plates were dried under a stream of warm air, the separated compounds visualized under ultraviolet light $(254 \mathrm{~nm})$, and scanned for radioactivity with an RTLC multi-scanner (Radiomatic Instruments \& Chemical Co., Inc., Tampa, FL).

Substrate concentration curve of EC ADPase. Aspirin-treated EC $(72,233 / 400 \mu \mathrm{l}$ total vol) in TSG buffer were incubated with stirring for $5 \mathrm{~min}\left(37^{\circ} \mathrm{C}\right)$ with $1.2-80.1 \mu \mathrm{M}$ ADP containing $2.4 \mu \mathrm{Ci}$ of $\left({ }^{3} \mathrm{H}\right) \mathrm{ADP}$ (trisodium salt, $27.3 \mathrm{Ci} / \mathrm{mmol}$; New England Nuclear), in the presence of $10 \mu \mathrm{M}$ dipyridamole. The latter was used to prevent reuptake of adenosine and consequent resynthesis of $\operatorname{ADP}(7,9) . \mathrm{Ca}^{++}(1.22 \mathrm{mM})$ was added $30 \mathrm{~s}$ before ADP. As in the time course experiments described above, tubes were then centrifuged, supernatants treated with stop solution, aliquots counted for total radioactivity, and TLC performed. The dipyridamole stock solution was prepared in glycine- $\mathrm{HCl}$ buffer $(0.05 \mathrm{M}, \mathrm{pH} 2.8)$. During these experiments, EC stock suspensions were stored at $4^{\circ} \mathrm{C}$.

$\left({ }^{14} \mathrm{C}\right)$ Serotonin, 5-hydroxytryptamine $(5-\mathrm{HT})$ release. For platelet labeling, $0.2 \mathrm{nmol}\left({ }^{14} \mathrm{C}\right) 5-\mathrm{HT}$ creatinine sulfate $(54 \mathrm{mCi} / \mathrm{mmol}$; Amersham Corp., Arlington Heights, IL) was added directly to the anticoagulant for each ml of anticoagulated blood. $\left({ }^{14} \mathrm{C}\right) 5$-HT uptake was determined $1 \mathrm{~h}$ after blood collection by comparison of radioactivity in 50- $\mu$ l aliquots of PRP and platelet-poor plasma. Assays of the effects of EC on platelet $\left({ }^{14} \mathrm{C}\right) 5$-HT release and aggregation were carried out in cuvettes in the usual manner, using $1 \times 10^{8}$ labeled platelets in suspension or PRP. To prevent reuptake of released 5-HT, imipramine (2.5 $\mu \mathrm{M})$ was added $90 \mathrm{~s}$ before the agonist. Controls containing labeled platelets without agonist were carried out to measure any release of $\left({ }^{14} \mathrm{C}\right)$ 5-HT attributable to stirring alone. Reactions were stopped $4 \mathrm{~min}$ after stimulation by placing the cuvettes on ice. Cuvette contents were transferred to microfuge tubes and centrifuged for $3 \mathrm{~min}(10,000 \mathrm{~g}$, $4^{\circ} \mathrm{C}$ ). $50-\mu 1$ aliquots of each supernatant were counted in $4 \mathrm{ml}$ Aquasol2 and compared to total platelet counts.

Additional methods. Treatment of platelets with methylene blue, an inhibitor of soluble guanylate cyclase, was essentially according to $\mathrm{Al}$ heid et al. (10). Methylene blue was added to a washed platelet suspension at a concentration of $10 \mu \mathrm{M}$. The suspension was then left at room temperature for $30 \mathrm{~min}$, centrifuged at $1,450 \mathrm{~g}\left(15 \mathrm{~min}, 4^{\circ} \mathrm{C}\right)$ and the pellet resuspended in cold $0.15 \mathrm{M} \mathrm{NaCl}$.

Oxyhemoglobin was prepared from bovine hemoglobin (type 1; Sigma Chemical Co., St. Louis, MO) by the method of Martin et al. (11). Human hemoglobin yielded identical results. Briefly, a 1-mM solution of the commercial mixture of oxyhemoglobin and methemoglobin was reduced with a 10 -fold molar excess of sodium dithionite, which was then removed by dialysis. Purity was checked spectrophotometrically and aliquots frozen at $-70^{\circ} \mathrm{C}$.

Adenosine-5'-O-(2-thiodiphosphate) trilithium salt (ADP- $\beta-S$ ) was obtained from Boehringer Mannheim, Indianapolis, IN.

Prostacyclin production was measured by RIA for 6-keto-PGF Pa $_{1 a}$ (DuPont-New England Nuclear).

\section{Results}

Endothelial cells inhibit platelet reactivity in totally aspirintreated systems. When ASA-treated washed platelets were stimulated by agonists in the presence of ASA-treated endothelial cells, platelet aggregation was inhibited (Fig. 1). This occurred under conditions where control ASA-platelets alone were fully aggregated by the same quantity of stimulus (Fig. 1). RIA measurements verified that no $\mathrm{PGI}_{2}$ had formed in these experi- 
Thrombin $(0.5 \mathrm{U} / \mathrm{ml})$

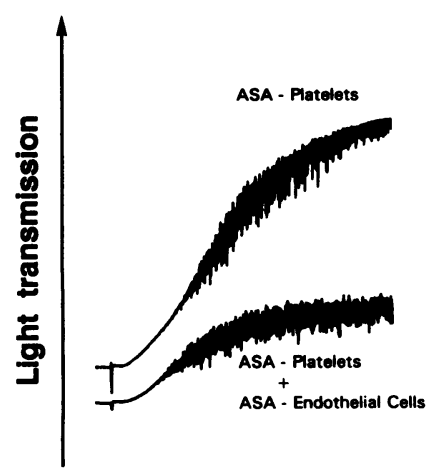

$1 \mathrm{~min}$

Figure 1. Inhibition of platelet aggregation by endothelial cell suspensions. The upper curves (controls) represent the response of washed, aspirin-treated platelets to thrombin and ionophore, respectively. The lower curves depict inhibited platelet responsiveness when aspirin-treated endothelial cells were present. Aspirin treatment of both cell types prevented transcellular metabolism of platelet endoperoxide to prostacyclin by the endothelial cells (2).

ments. As shown in Fig. $2 A$, PRP from a donor who had ingested aspirin was fully aggregated by $1 \mu \mathrm{M}$ ADP. In contrast, when this PRP was stimulated in the presence of $1 \times 10^{6} \mathrm{ASA}$ EC, the inhibited aggregation curve was characterized by a brief ascending limb followed by reversal. The pattern of reversibility was reminiscent of previous experiments in this laboratory wherein ADP released from platelets by $\mathrm{PGH}_{2}$ was intentionally removed by enzymatic means (apyrase) (Fig. $2 B$ ).

Concurrent metabolism of ADP by endothelial cells and loss of its potential as a platelet agonist. The hypothesis that an ADPase activity was present on these human endothelial cells and could possibly account for their platelet-inhibitory properties was tested biochemically and functionally. $\left({ }^{14} \mathrm{C}\right) \mathrm{ADP}(15$ $\mu \mathrm{M})$ was incubated with ASA-EC for increasing periods of time. The supernatants were then examined for their content of residual $\left({ }^{14} \mathrm{C}\right) \mathrm{ADP}$ and its metabolites, as well as for the platelet aggregating potential of the unmetabolized $\left({ }^{14} \mathrm{C}\right) \mathrm{ADP}$. Re-
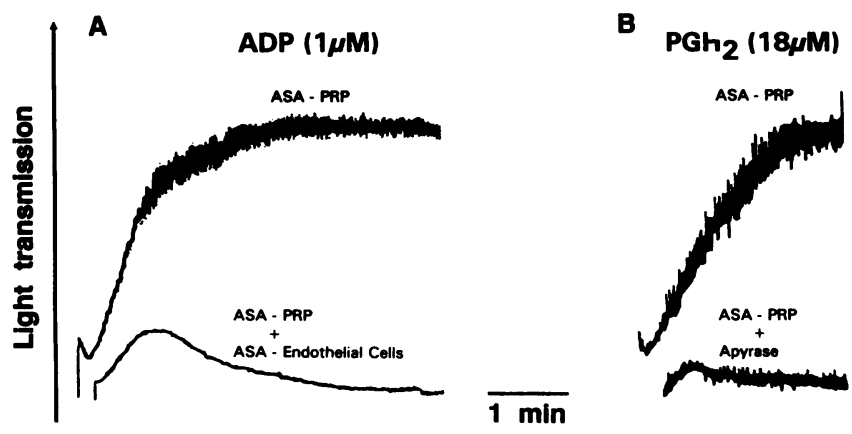

Figure 2. Comparison of the inhibition of ADP-induced aggregation in PRP by endothelial cells $(A)$, with that due to enzymatic removal by apyrase of platelet ADP released by prostaglandin endoperoxide $\left(\mathrm{PGH}_{2}\right)$ stimulation $(B)$. Similarities in the shapes of the curves of inhibited aggregation (lower curves) suggest enzymatic removal of ADP in $A$ as well.

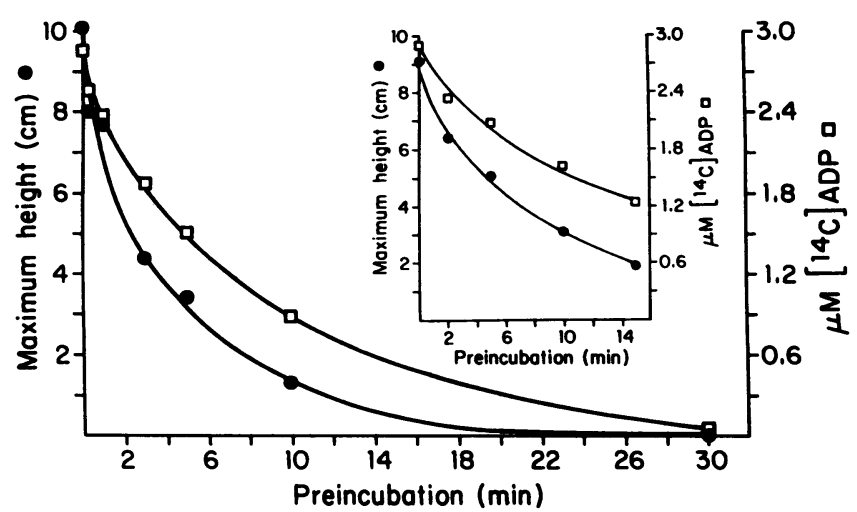

Figure 3. Time course of metabolism of $\left({ }^{14} \mathrm{C}\right)$ ADP by aspirin-treated endothelial cell suspensions. The decrease in $\left({ }^{14} \mathrm{C}\right)$ ADP concentration as measured by thin-layer radiochromatography ( $\square-$ ), was accompanied by loss of platelet proaggregatory activity ( $-\bullet-)$ of supernatants derived from incubation of endothelial cells with $\left({ }^{14} \mathrm{C}\right)$ ADP. This also occurred when endothelial cell monolayers were used (inset). Results shown are from representative experiments in which 72,215 suspended EC or $84,625 \mathrm{EC}$ in monolayers were assayed.

sults are depicted in Figs. 3 and 4. When compared to $\left({ }^{14} \mathrm{C}\right)$ ADP controls which had been incubated with buffer alone, the presence of EC resulted in a progressive decrease in $\left({ }^{14} \mathrm{C}\right) \mathrm{ADP}$ concentration. This was paralleled by loss of supernatant proaggregatory activity as measured by the decrease in maximum height of the platelet aggregation curves. Comparable results were obtained whether endothelial cell suspensions (Fig. 3) or monolayers (Fig. 3, inset) were employed. ADPase activity was also present on freshly adherent, but uncultured endo-

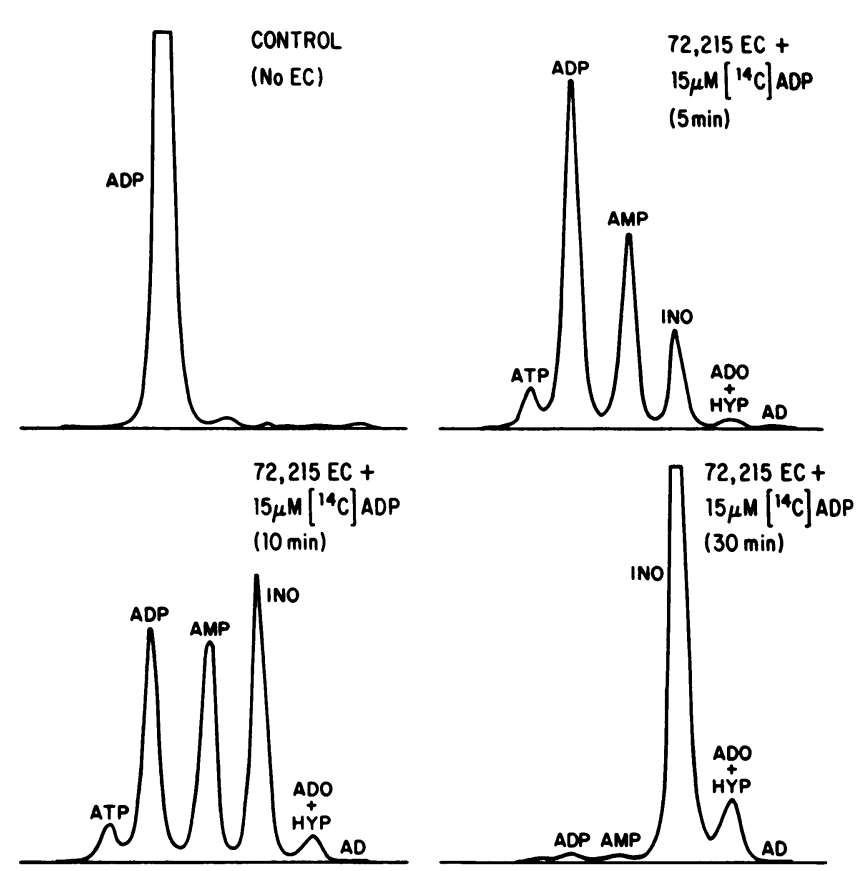

Figure 4. Time course of formation of metabolites of $\left({ }^{14} \mathrm{C}\right)$ ADP by aspirin-treated endothelial cell suspensions. Cell-free supernatants derived from incubations of endothelial cells with $\left({ }^{14} \mathrm{C}\right)$ ADP were analyzed for $\left({ }^{14} \mathrm{C}\right)$ ADP and its metabolites by TLC. 


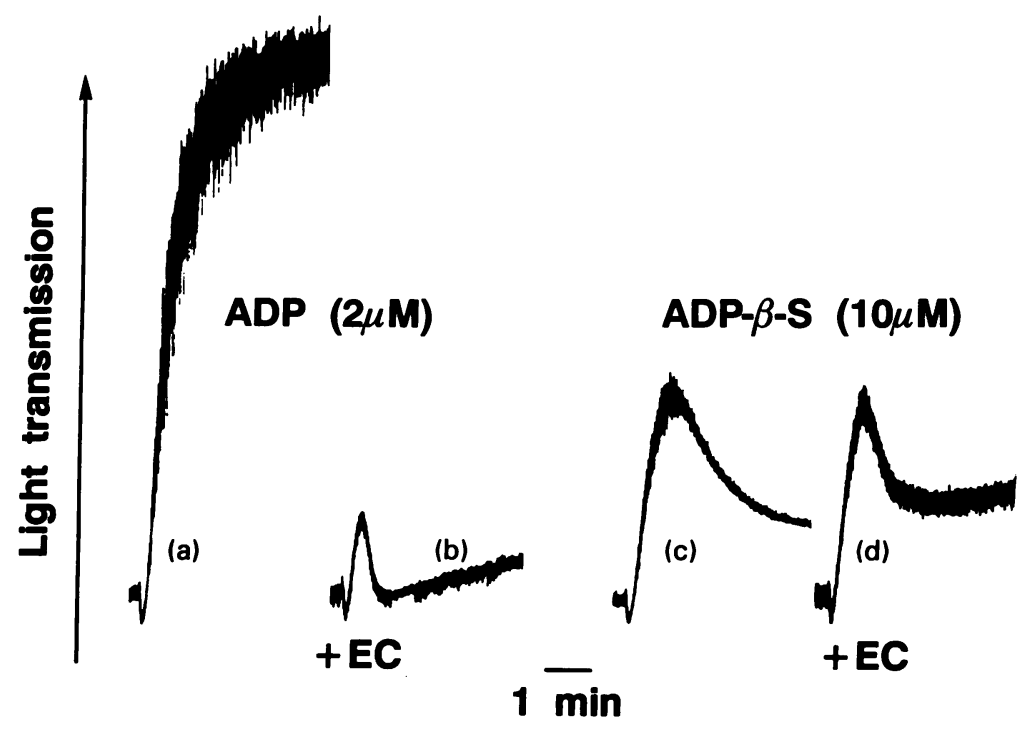

Figure 5. Studies with ADP- $\beta$-S, a nonmetabolizable ADP analogue that activates platelets. (a) ADP elicited a full aggregation response in aspirin-treated platelets. $(b)$ Inhibition of the ADP response by aspirin-treated endothelial cells. (c) Aggregation response of aspirin-treated platelets to ADP- $\beta$-S. (d) Aggregation induced by ADP$\beta$-S was not appreciably influenced by the presence of endothelial cells, which were unable to metabolize the ADP- $\beta-S$. thelial cells. There was only a slight decrease in ADPase activity concomitant with cell passage. Fig. 4 depicts radio-TLC scans of the metabolites of $\left({ }^{14} \mathrm{C}\right) \mathrm{ADP}$ after 5,10 , and 30 min incubation with ASA-EC suspensions. At the 5-min time point, ADP had decreased to $51 \%$ of total nucleotides, nucleosides, and bases. In addition, AMP (28\%) and inosine (13\%) were identified, together with trace quantities of adenosine, hypoxanthine, and adenine. By $10 \mathrm{~min}$, concentrations of ADP, AMP, and inosine averaged $30 \%, 29 \%$, and $29 \%$, respectively. Inosine $(85 \%)$ was the major $\left({ }^{14} \mathrm{C}\right)$ ADP metabolite at the 30 -min interval, and ADP itself was virtually absent. Chromatography with solvent system 2 indicated that hypoxanthine $(8 \%)$ had been synthesized. As can be seen in Fig. 3, the absence of ADP correlated with total loss of aggregatory activity of the ASA-EC supernatant.

The presence or absence of endothelial cells did not affect the recovery of total radioactivity in supernatants. This indicated that nonspecific adsorption of ADP to the endothelial cells was not the cause of the decrease in supernatant proaggregatory activity.
Endothelial cell inhibition of ADP-induced platelet reactivity requires $A D P$ hydrolysis. Experiments were carried out with ADP- $\beta-S$, a structural analogue of ADP that activates platelets, but is not metabolized by ADPases (12). As shown in Fig. 5, ASA-platelets stimulated alone with $2 \mu \mathrm{M}$ ADP demonstrated a full aggregation response $(a)$. In the presence of $1 \times 10^{6} \mathrm{ASA}$ $\mathrm{EC}$, this response was markedly attenuated and reversed $(b)$. ADP- $\beta-S(10 \mu \mathrm{M})$ induced a reversible aggregation response of lesser amplitude than ADP $(2 \mu \mathrm{M})$ with ASA-platelets alone (c). However, in contrast to results with ADP, ASA-EC did not exert an appreciable inhibitory effect on ADP- $\beta$-S-stimulated ASA-platelets $(d)$. These results provided further evidence for ADP hydrolysis by EC as a major mechanism underlying their inhibitory effect on stimulated platelets.

Kinetic parameters of human endothelial cell ADPase. We measured the rate of hydrolysis of $\left({ }^{3} \mathrm{H}\right)$ ADP by ASA-EC as a function of substrate concentration. Apparent $K_{\mathrm{m}}$ and $V_{\max }$ values were determined from Lineweaver-Burk plots of the data (Fig. 6). In two experiments, the $K_{\mathrm{m}}$ ranged from 33 to 42 $\mu \mathrm{M}$ and the $V_{\max }$ from 17 to $43 \mathrm{nmol} / \mathrm{min}$ per $10^{6}$ cells. These

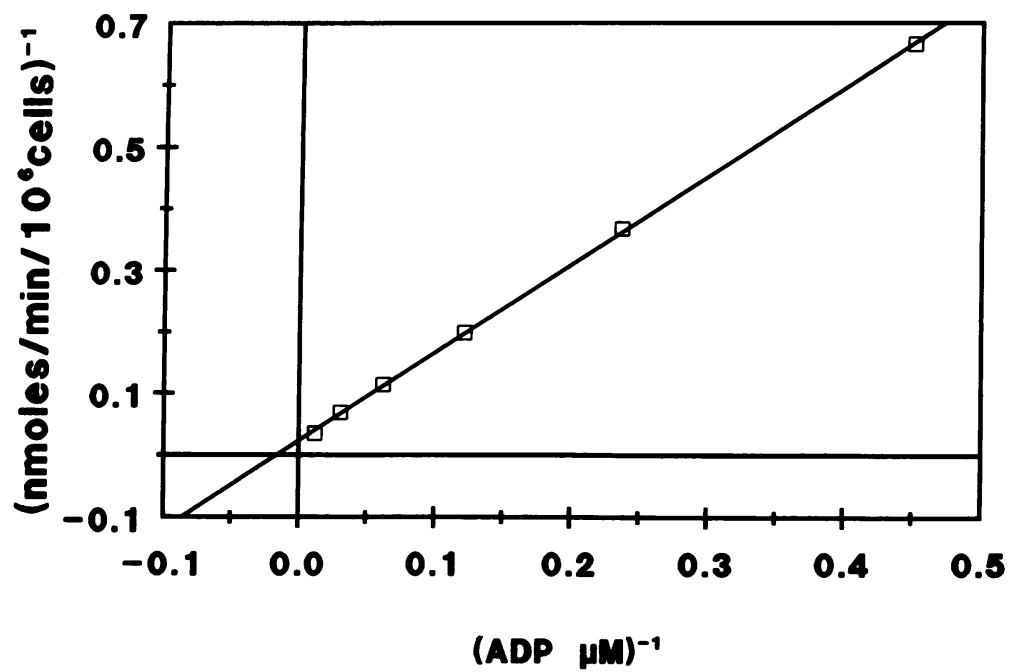

Figure 6. Lineweaver-Burk plot relating the rate of $\left({ }^{14} \mathrm{C}\right)$ ADP hydrolysis by aspirin-treated endothelial cells to ADP concentration. The $K_{\mathrm{m}}$ calculated from these data was $33 \mu \mathrm{M}$ and the $V_{\max }$ was $42.5 \mathrm{nmol} / \mathrm{min}$ per $10^{6}$ cells. Results depicted are representative of two separate experiments. 
kinetic parameters are compared in Table I with values reported in the literature for porcine aortic endothelial cells $(13,14)$.

Endothelial cell ADPase inhibits platelet reactivity independent of EDRF. ASA-endothelial cells (which did not produce $\mathrm{PGI}_{2}$ ), inhibited platelet aggregation by an aspirin-insensitive mechanism. This inhibition could have been due in part to a fluid phase reactant such as EDRF in combination with the EC ADPase activity described above. To test this possibility, known modulators of EDRF activity were added to the platelet-EC incubations. Inhibition of platelet aggregation by endothelial cells was not affected by: $(a)$ hemoglobin or ferrous ion, which inactivate EDRF/nitric oxide (NO); (b) methylene blue, which prevents the effects of EDRF/NO by inhibiting soluble guanylate cyclase; or $(c)$ superoxide dismutase, a potentiator of EDRF/NO via removal of superoxide radicals.

Supernatants of EC that had been previously stimulated (15 s) with bradykinin, acetylcholine, or histamine were rapidly transferred to cuvettes containing platelets. There was little $(<10 \%)$ if any inhibition of ADP, thrombin, or collagenstimulated platelet aggregation. This indicated that the platelet inhibitory activity observed in the presence of ASA-endothelial cells was not transferable, and therefore was mainly surface associated. When endothelial cells were prestimulated with thrombin, the quantity present in the transferred supernatant served as agonist in the aggregometry cuvette. Since the same degree of aggregation was obtained with this supernatant (even after a 3-min incubation of thrombin with EC) as with thrombin alone, nonspecific adsorption of agonist to the EC could again be ruled out as the possible etiology of platelet inhibition.

Release of $\left({ }^{14} \mathrm{C}\right)$ 5-HT from stimulated platelets was used as another parameter to gauge the effects of ASA-endothelial cells on platelet reactivity. ASA-endothelial cells inhibited 5-HT release from activated platelets as well as their aggregation (Table II). Hemoglobin did not reverse the inhibitory effect of the ASA-endothelial cells on either 5-HT release or aggregation.

Endothelial cells reverse the capacity of thrombin-elicited platelet releasates to enhance platelet aggregation. To more closely relate the loss of thrombin-induced proaggregatory ac-

Table I. Kinetic Parameters for Endothelial Cell ADPases from Different Sources

\begin{tabular}{lccc}
\hline & $K_{\mathrm{m}}$ & $V_{\max }$ & $V_{\max } / K_{\mathrm{m}}$ \\
\hline & $\mu M$ & $n m o l /$ min per $10^{6}$ cells & \\
$\begin{array}{l}\text { Human umbilical vein } \\
\text { endothelial cells }\end{array}$ & 38 & 30 & 0.789 \\
$\begin{array}{l}\text { Porcine aortic endothelial } \\
\text { cells (13) }\end{array}$ & 155 & 9.2 & 0.059 \\
$\begin{array}{l}\text { Porcine aortic endothelial } \\
\text { cells (14) }\end{array}$ & 247 & 6.2 & 0.025 \\
\end{tabular}

Aspirin-treated endothelial cells were incubated with $\left({ }^{3} \mathrm{H}\right)$ ADP. After $5 \mathrm{~min}$ the tubes were centrifuged and thin-layer chromatography performed on the supernatants. The rate of hydrolysis of ADP was measured as a function of substrate concentration. Apparent $K_{\mathrm{m}}$ and $V_{\max }$ values were determined from Lineweaver-Burk plots as shown in Fig. 6. Values for human umbilical vein endothelial cells represent averages from two separate experiments. These parameters are compared with values reported in the literature.
Table II. Inhibition of Serotonin Release from Stimulated Aspirin-treated Platelets by Aspirin-treated Endothelial cells

\begin{tabular}{lcc}
\hline & \multicolumn{2}{c}{ Serotonin release (\%) } \\
\cline { 2 - 3 } & Collagen & Thrombin \\
\hline & $10 \mu \mathrm{g} / \mathrm{ml}$ & $0.3 \mathrm{U} / \mathrm{ml}$ \\
Platelets alone & 68 & 66 \\
$+1 \times 10^{6}$ endothelial cells & 26 & 0 \\
$+1 \times 10^{6}$ endothelial cells + & & \\
$\quad$ hemoglobin $(20 \mu \mathrm{M})$ & 15 & 4 \\
$+0.5 \times 10^{6}$ endothelial cells & 48 & - \\
$+0.5 \times 10^{6}$ endothelial cells + & & - \\
hemoglobin $(20 \mu \mathrm{M})$ & 31 & \\
\hline
\end{tabular}

Values represent radioactive serotonin released into the supernatant, as percent of total radioactive serotonin in the labeled platelets. Hemoglobin was used as an inhibitor of EDRF/NO activity. If the inhibition of serotonin release were due to EDRF/NO, the inhibition of release would have been reversed in the presence of hemoglobin. These results are representative of four separate experiments.

tivity to EC ADPase action, the following experiments were performed. Supernatants from platelets that had been stimulated with thrombin $(1 \mathrm{U} / \mathrm{ml})$ in the absence or presence of endothelial cells were used as agonists for platelet aggregation. Curve $(a)$ in Fig. 7 was generated by the threshold level of thrombin $(0.2 \mathrm{U} / \mathrm{ml})$ transferred from the incubation tube to the aggregometry assay cuvette. The enhanced aggregation response in curve $(c)$ was evoked by the combined presence of transferred thrombin-induced platelet releasate in addition to transferred thrombin in the supernatant. Comparable synergy was demonstrated in control experiments in which thrombin $(0.2 \mathrm{U} / \mathrm{ml})$ plus concentrations of ADP expected to be released during the initial incubation were added directly to the aggregometer cuvette (data not shown). The presumed concentration of ADP released into the incubation tube, calculated from values reported in the literature (15) was $6.25 \mu \mathrm{M}$. The kinetic parameters we derived for the human endothelial cell ADPase under study indicate that this quantity of ADP would have been hydrolyzed by the $2 \times 10^{6}$ EC present during our 5-min incubation. It can be seen in curve $(b)$ Fig. 7 that the presence of EC did indeed reverse the enhanced aggregation.

\section{Discussion}

In our earlier studies of platelet responsiveness to agonists when in combined suspension with human endothelial cells, we correlated the observed inhibition of platelet aggregation with prostacyclin formation (2). Under those experimental conditions, the endothelial cells had been pretreated with aspirin, but the platelets were not. Prostacyclin formation was demonstrated to result from metabolism of platelet-derived endoperoxides by endothelial cells in apposition. In the last decade, at least two endothelial cell-associated platelet inhibitory substances in addition to $\mathrm{PGI}_{2}$ have been identified. These are endothelial cell ecto-ADPases $(9,16)$ and the endothelium-derived relaxing factor (EDRF/NO) (17-20). Production of EDRF and the action of endothelial cell ADPases are insensitive to aspirin and could have contributed at least in part to results observed in earlier studies (2). 


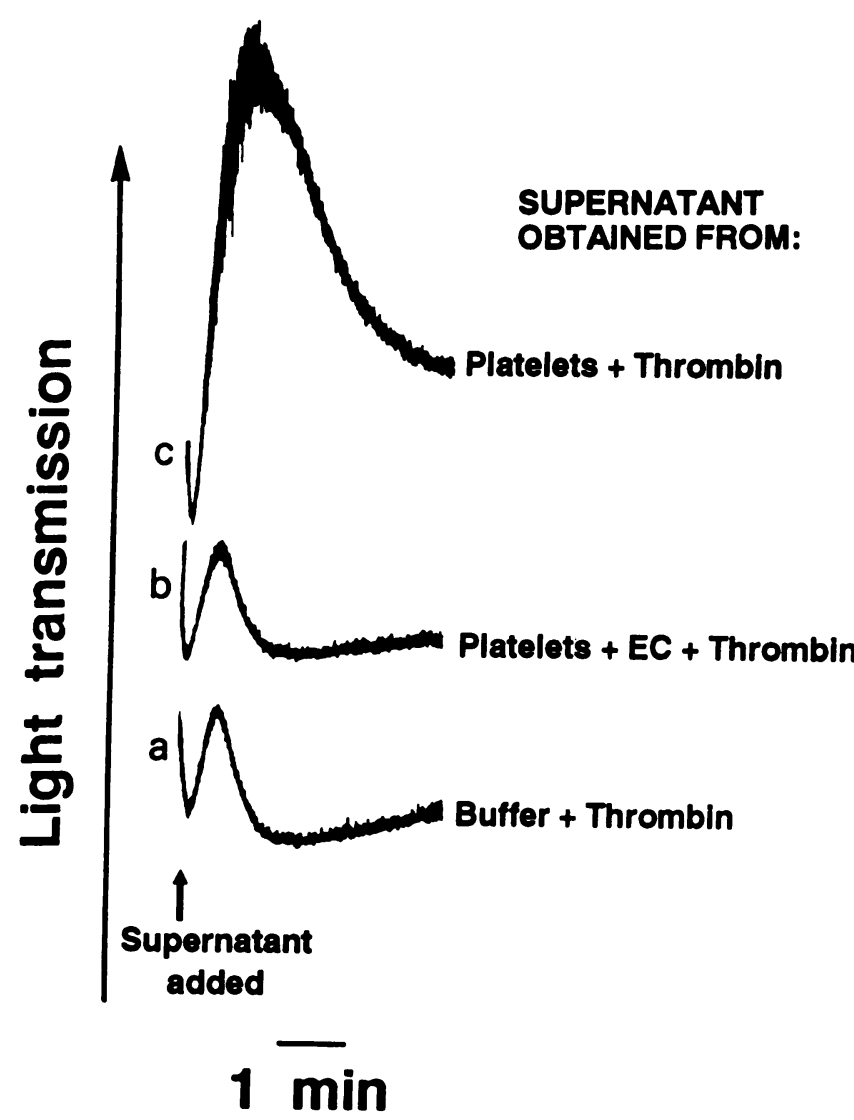

Figure 7. Aggregation response of platelets in PRP to supernatants derived from thrombin-stimulated platelets or thrombin-stimulated platelet-endothelial cell mixtures. (a) Aggregation due to thrombin carried over in the supernatant of a buffer control which contained no cells. In $(c)$ the presence of thrombin-induced platelet releasate in the supernatant produced an enhanced aggregation response. The enhancement of supernatant aggregatory potency as shown in $(c)$ was reversed by the interaction of endothelial cell ADPase with the platelet releasate as shown in $(b)$.

We therefore performed experiments using both aspirintreated platelets and aspirin-treated endothelial cells, thereby eliminating production of any cyclooxygenase-derived eicosanoids. As shown in Figs. 1 and 2 and Table II, endothelial cells inhibited platelet responsiveness to all agonists tested even when the entire system was aspirin-treated. The endothelial cell-induced inhibition was cell associated since the inhibitory activity was not present in supernatants from endothelial cells even when they had been stimulated with known agonists for EDRF/NO. Substances known to reverse or enhance EDRF/ NO activity had no influence on the inhibitory effects of endothelial cells on the platelet responsiveness observed in these experiments. This is shown for hemoglobin in Table II.

When ADP-induced platelet aggregation was reversed in the presence of endothelial cells, the shape of the recorded pattern of reversal suggested that ADP had been enzymatically removed (Fig. 2). In this regard, it was possible to biochemically and functionally correlate metabolism of ADP by ASAEC with disappearance of its properties as an agonist for platelet aggregation (Figs. 3 and 4). The fact that similar activity was demonstrable with either endothelial cell suspensions or adherent monolayers suggests that the ADPase activity is located on the luminal surface of the vessel and would interface directly with platelets. Comparable results have been reported by Crutchley and associates with bovine pulmonary arterial endothelial cells (7) and Glasgow et al. with human endothelial cell monolayers (21).

As shown in Table I, values obtained with our human endothelial cell preparations for the apparent $K_{\mathrm{m}}$ and catalytic efficiency $\left(V_{\max } / K_{\mathrm{m}}\right)$ with ADP as substrate, compared favorably with those reported for porcine aortic endothelial cells $(13,14)$. Calculations using these figures indicate that the quantity of ADP hydrolyzable by our endothelial cell suspensions would be sufficient to result in inhibition of platelet aggregation. For example, $0.5 \times 10^{6} \mathrm{EC}$ would metabolize $2 \mu \mathrm{M}$ ADP to $0.8 \mu \mathrm{M}$ in $30 \mathrm{~s}$.

In the case of agonists other than ADP, such as thrombin, collagen, and ionophore, hydrolysis of released platelet ADP may also be involved in the loss of platelet responsiveness (Fig. 1, Table II). Calculations based on results depicted in Fig. 7 indicated that enhancement of threshold thrombin aggregation was attributable to thrombin-released platelet ADP. Removal of this ADP by endothelial ecto-ADPase reversed the enhancement, and aggregation reverted to the original threshold level. This occurred in the total absence of endothelial cell $\mathrm{PGI}_{2}$ and EDRF and emphasizes the role of endothelial cell ADPases in control of platelet recruitment.

A major reason for elucidating biochemical and functional properties of endothelial cell-associated ecto-ADPases is that they can exert a significant effect on platelet reactivity independent of the action of other known endothelium derived inhibitors. For evaluation of the entire known spectrum of EC control of platelet reactivity ("thromboregulation"), cell preparations which simultaneously produce $\mathrm{PGI}_{2}, \mathrm{EDRF} / \mathrm{NO}$, and possess ADPase activity will require additional assessment. It is also possible that as yet undefined endothelial cell thromboregulators could have contributed to results obtained by ourselves and others.

\section{Acknowledgments}

We thank Drs. Juana Valles and M. Teresa Santos for helpful discussions and suggestions, and Ms. Evelyn M. Ludwig for her expert editorial contributions.

This work was supported by grants from the Department of Veterans Affairs Medical Center, National Institutes of Health grants HL18828-16 SCOR (Drs. Marcus and Broekman), HL-47073-01, HL46403 (Drs. Marcus, Hajjar, and Broekman), HL-29034 (Dr. Broekman), HL-42493 (Dr. Hajjar), the Edward Gruenstein Fund, the S. M. Louis Fund, and the Sallie Wichman Fund (Dr. Marcus). Dr. Hajjar is an Established Investigator of the American Heart Association and a Syntex Scholar (1989).

\section{References}

1. Marcus, A. J. 1990. Thrombosis and inflammation as multicellular processes. Pathophysiological significance of transcellular metabolism. Blood. 76:1903-1907.

2. Marcus, A. J., B. B. Weksler, E. A. Jaffe, and M. J. Broekman. 1980. Synthesis of prostacyclin from platelet-derived endoperoxides by cultured human endothelial cells. J. Clin. Invest. 66:979-986.

3. Marcus, A. J. 1990. Eicosanoid interactions between platelets, endothelial cells and neutrophils. Methods Enzymol. 187:585-599.

4. Hajjar, K. A., P. C. Harpel, E. A. Jaffe, and R. L. Nachman. 1986. Binding of plasminogen to cultured human endothelial cells. J. Biol. Chem. 261:1165611662. 
5. Lüthje, J., A. Schomburg, and A. Ogilvie. 1988. Demonstration of a novel ecto-enzyme on human erythrocytes, capable of degrading ADP and of inhibiting ADP-induced platelet aggregation. Eur. J. Biochem. 175:285-289.

6. Cooper, D. R., G. P. Lewis, G. E. Lieberman, H. Webb, and J. Westwick 1979. ADP metabolism in vascular tissue, a possible thrombo-regulatory mechanism. Thromb. Res. 14:901-914.

7. Crutchley, D. J., U. S. Ryan, and J. W. Ryan. 1980. Effects of aspirin and dipyridamole on the degradation of adenosine diphosphate by cultured cells derived from bovine pulmonary artery. J. Clin. Invest. 66:29-35.

8. Norman, G. A., M. J. Follett, and D. A. Hector. 1974. Quantitative thinlayer chromatography of ATP and the products of its degradation in meat tissue. J. Chromatogr. 90:105-111.

9. Pearson, J. D., J. S. Carleton, and J. L. Gordon. 1980. Metabolism of adenine nucleotides by ectoenzymes of vascular endothelial and smooth-muscle cells in culture. Biochem. J. 190:421-429.

10. Alheid, U., J. C. Frölich, and U. Förstermann. 1987. Endotheliumderived relaxing factor from cultured human endothelial cells inhibits aggregation of human platelets. Thromb. Res. 47:561-571.

11. Martin, W., G. M. Villani, D. Jothianandan, and R. F. Furchgott. 1985 Selective blockade of endothelium-dependent and glyceryltrinitrate-induced relaxation by hemoglobin and methylene blue in rabbit aorta. J. Pharmacol. Exp. Ther. 232:708-716.

12. Goody, R. S., F. Eckstein, and R. H. Schirmer. 1972. The enzymatic synthesis of thiophosphate analogs of nucleotides. Biochim. Biophys. Acta. 276:155-161

13. Cusack, N. J., J. D. Pearson, and J. L. Gordon. 1983. Stereoselectivity of ectonucleotidases on vascular endothelial cells. Biochem. J. 214:975-981.
14. Gordon, E. L., J. D. Pearson, and L. L. Slakey. 1986. The hydrolysis of extracellular adenine nucleotides by cultured endothelial cells from pig aorta. Feed-forward inhibition of adenosine production at the cell surface. J. Biol. Chem. 261:15496-15507.

15. Holmsen, H., C. A. Setkowsky, B. Lages, H. J. Day, H. J. Weiss, and M. C. Scrutton. 1975. Content and thrombin-induced release of acid hydrolases in gelfiltered platelets from patients with storage pool disease. Blood. 46:131-142.

16. Lieberman, G. E., G. P. Lewis, and T. J. Peters. 1977. A membrane-bound enzyme in rabbit aorta capable of inhibiting adenosine-diphosphate-induced platelet aggregation. Lancet. ii:330-332.

17. Furchgott, R. F., and J. V.Zawadzki. 1980 . The obligatory role of endothelial cells in the relaxation of arterial smooth muscle by acetylcholine. Nature (Lond.). 288:373-376.

18. Palmer, R. M. J., A. G. Ferrige, and S. Moncada. 1987. Nitric oxide release accounts for the biological activity of endothelium-derived relaxing factor. Nature (Lond.). 327:524-526.

19. Ignarro, L. J. 1990. Biosynthesis and metabolism of endothelium-derived nitric oxide. Annu. Rev. Pharmacol. Toxicol. 30:535-560.

20. Broekman, M. J., A. M. Eiroa, and A. J. Marcus. 1991. Inhibition of human platelet reactivity by endothelium-derived relaxing factor from human umbilical vein endothelial cells in suspension. Blockade of aggregation and secretion by an aspirin-insensitive mechanism. Blood. 78:1033-1040.

21. Glasgow, J. G., R. Schade, and F. A. Pitlick. 1978. Evidence that ADP hydrolysis by human cells is related to thrombogenic potential. Thromb. Res. 13:255-266. 